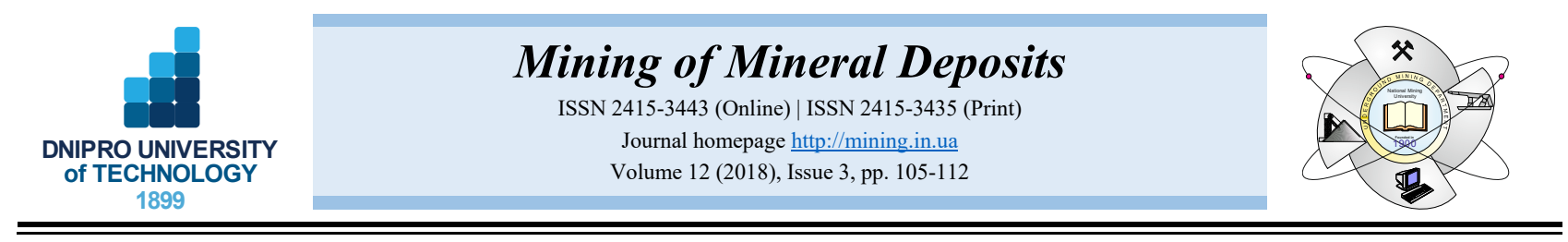

UDC 622.5:504.06

https://doi.org/10.15407/mining12.03.105

\title{
MITIGATING THE ADVERSE ENVIRONMENTAL IMPACT RESULTING FROM CLOSING DOWN OF MINING ENTERPRISES
}

\author{
V. Kostenko ${ }^{1}$, O. Zavialova ${ }^{1}$, O. Chepak $^{1 *}$, V. Pokalyuk ${ }^{2}$ \\ ${ }^{\prime}$ Donetsk National Technical University, Pokrovsk, Ukraine \\ ${ }^{2}$ National University of Civil Defence of Ukraine, Kharkiv, Ukraine \\ *Corresponding author: e-mail olha.chepak@donntu.edu.ua, tel. +380957331747
}

\begin{abstract}
Purpose is to mitigate the adverse environmental impact in the context of both territory and water resources while closing down of mining enterprises.

Methods. Experiments and laboratory studies were carried out to determine a relationship between salt content and amount of common reed biomass buildup. Twelve reed tillers from a $50 \mathrm{~m}^{3}$ pond in Donetsk Region were selected for the research; water is habitat for eight of the tillers, and remaining four tillers grow at the distance of up to a meter from the water level. Water and air temperature, length of the reed stems as well as their diameters were recorded during thirty-eight weeks (i.e. March - November). The amount of suspended matters was determined when filtration residues of $50 \mathrm{ml}$ sample were dried out by means of a drier with their following weighing; total salt content within the water under study was identified using a weight method while evaporating $50 \mathrm{ml}$ of the filtered water sample volume and its residue drying out.

Findings. A relationship between salt content and common reed biomass buildup was confirmed; moreover, temperature range was determined in the context of which the greatest biomass buildup was observed basing upon the analysis of higher water plants use to purify high-mineralized turbid water. A scheme of air-lift drainage has been improved as for the drainage water disposal in the context of mines closed down by means of a wet method; the scheme makes it possible to control temperature of water being pumped out while varying a depth of water withdrawal from a mine shaft and helping provide practically year-round bioplateau action.
\end{abstract}

Originality. For the first time, optimum thermal water conditions (i.e. $12-22^{\circ} \mathrm{C}$ ) within a biopurification plant at the territory of a closed-down mine have been determined theoretically and confirmed experimentally; the conditions provide year-round $32 \%$ decrease in total salt content of water as well as $35 \%$ decrease in the amount of suspended matters.

Practical implications. The obtained results are applicable to rehabilitate fertile soil layer within the disturbed territories of facilities of the closed down mining enterprises with simultaneous waste purification from salts and suspended matters.

Keywords: reclamation, biodiversity, bioplateau, fertile soil layer, higher water plants, closed-down mine

\section{INTRODUCTION}

Land fund allocates considerable territories for the arrangement and operation of mining enterprises. Location of industrial sites, tailing ponds, and waste piles within the territories factors into degradation and disturbance of a fertile layer of the earth's surface. After enterprise liquidation, natural reclamation of the disturbed territories up to their virgin state slows down due to a number of reasons; deficiency of water and fertile soil for activity of biota are among them.

According to the Land Code of Ukraine, mine liquidation is followed by the process when industrial sites should be restored up to the state being suitable for further use inclusive of agricultural needs.

Currently, only 104 Donbas coal mines of 227 ones operate properly; 106 mines are under reorganization. No more than 17 coal mines of 35 completely flooded ones operate under water drainage conditions (Denisov \& Averin, 2017).

In addition to its contamination by mechanical and organic impurities, mine water is characterized by high salt content. Out of adequate purification, its use for industries, households, and agriculture is limited; moreover, it is really dangerous from the viewpoint of contamination of water areas (Dolina, 2000).

(C) 2018. V. Kostenko, O. Zavialova, O. Chepak, V. Pokalyuk. Published by the Dnipro University of Technology on behalf of Mining of Mineral Deposits. This is an Open Access article distributed under the terms of the Creative Commons Attribution License (http://creativecommons.org/licenses/by/4.0/), which permits unrestricted reuse, distribution, and reproduction in any medium, provided the original work is properly cited. 
Large-scale flooding of Donbas coal mines results in the contamination of both underground and surface water as well as in underflooding of adjacent areas and intensified soil subsidence; subsequently, it may factor into the reason when different communication lines, buildings, and structures are removed from operation.

Annually, Ukrainian coal enterprises throw off more than 700 million cubic meters of mineralized water into hydrologic network; to neutralize it, 5- to 12-fold dilution with natural water is required which results in good-quality water degradation (Reznikov, L'vov, \& Kul'chenko, 2003).

Due to underfinancing of coal mining enterprises of the region as well as worn-out water-treating facilities, the major portion of the pumped mine water is thrown off into water bodies with no treatment; the process results in their eutrophication and muddying.

After the abandoned mines were liquidated by means of a wet technique and combined one, water drainage is required from the flooded mine workings (depth should not be less than $100 \mathrm{~m}$ ) to prevent underflooding of a subsided surface. In this context, the pumped water should be treated and desalted before its getting to a surface water body. Currently, desalination of such flows is a technical problem associated with significant expenditures.

Thus, mitigation of environmental hazard in the process of mine enterprise liquidation is connected with the solution of the two key environmental problems:

- intensive reclamation of the disturbed territories and their getting back to land fund of Ukraine;

- better quality of the pumped mine water applicable for its further integrated use by industries and agriculture.

\subsection{Analysis of previous research}

Practices concerning reclamation of the disturbed territories apply agricultural, forestry, sanitary, constructional, landscaping, and hydroeconomic recultivation techniques. The technique is selected depending upon climatic zone, zonal biodiversity, economic feasibility, designated use, and permitted use.

Natural self-recovery of land is proposed as an alternative to technical and agricultural recultivation to rehabilitate territories of the liquidated industrial enterprises and preserve valuable flora being typical for the region (Tropek \& Konvicka, 2008; Chuman, 2015). Slow revegetation is among disadvantages of the method. If fertile soil layer and ample moisture are available, then self-revegetation period takes 10 to 15 years; if the lands are arid, then the period is more than 20 years.

To restore biodiversity of the disturbed territories, forest recultivation, when deciduous trees and conifers are planted, is applied (Ivakina \& Osipov, 2016). Slow tree growth (average period of a complete landscaping of a territory is 15 to 25 years), and low survival rate of many conifer types during rainless periods are the major disadvantages of the proposed method.

The abovementioned recultivation techniques cannot solve the problem concerning the improvement of the discharged mine water. It is required to apply techniques being intended to the improvement of water pumped from the abandoned mines.

Mine water contains (Didukh \& Aloshkina, 2007):

- suspended matters and mechanical impurities being mainly composed of fine coal and rock particles;
- dissolved matters mainly in the form of chlorides and sulphates of different metals;

- salts of heavy metals being a part of mine water as a result of rock leaching;

- organic impurities (i.e. petrochemicals, and phenols);

- contaminants (i.e. bacteria).

Chemical composition of mine water depends directly upon composition and properties of rocks enclosing a mineral and upon a composition of underground water getting to a mine working. In terms of $\mathrm{pH}$ factor, mine water is divided into three types: acid water $(\mathrm{pH}<6.5)$, neutral water $(6.5-8.5)$, and alkaline water $(>8.5)$. In terms of salt content, there may be fresh water (when solid residue is to $1000 \mathrm{mg} / \mathrm{l}$ ), salty water (when solid residue is 1000 to $3000 \mathrm{mg} / \mathrm{l}$ ), saline water (when solid residue is 3000 to $10000 \mathrm{mg} / \mathrm{l}$ ), and salt water (when solid residue is more than $10000 \mathrm{mg} / \mathrm{l}$ ). The main share of mine water in Donbas (almost $85 \%$ ) belongs to salty and saline one; average salinity level is $2700 \mathrm{mg} / \mathrm{l}$ (Grebenkin, Kostenko, \& Matlak, 2008).

Hence, mine water is a multicomponent thermodynamical system containing gases, mineral substances and organic substances in the form of solutions and suspensions (Kostenko, Mnukhin, \& Omelchenko, 2013).

Depending upon original physical and chemical composition of mine water as well as its further use, mechanical, chemical, physical and chemical, and biological methods are applied. Ionic exchange, high-temperature technique, electrodialysis, and reverse osmosis are used to demineralize water and to desalt it (Gusev, Kaplunov, \& Podsevalov, 2010).

Ionic exchange method helps obtain the purest water; the system is reliable giving no response to a mineralization degree of source water and involving minor expenses connected with its equipment. Environmental contamination with toxic waste chemicals, and high cost of reagents are basic disadvantages of the technique; moreover, disposal of waste and filter elements are rather not easy processes.

Water demineralization using electrodialysis is recommended for the water where salt content is 1500 to $1700 \mathrm{mg} / \mathrm{l}$. in this context, salinity may be reduced down to $500-600 \mathrm{mg} / \mathrm{l}$. Further decrease in salt content involves increased power costs. Severe requirements for the quality of water supplied to the electrodialysis demineralizers are the technique disadvantage. Preliminary water clarification using coagulation and filtration should be involved. Moreover, after the electrodialysis, the water has to be infiltrated by means of sorption coal canisters to stop possible products of transformation of organic matters under the effect of electrodialysis.

Water demineralization by means of reverse osmosis does not involve any chemical reagents while being a high-degree water treatment technique; however, for the moment, membrane cartridges are expensive, ineffective, and easily intoxicated.

In terms of the liquidated mining enterprises, characterized by relatively insignificant sewage water flow, biological demineralization, a technique using high hydrobionts, is acceptable. Low cost, no electricity, and ease of biological structures operation are the method advantages (Kaplan, 2012).

Such high water plants as water hyacinth, common reed, cattail, and bulrush are used traditionally for bio- 
logical water treatment (Romanchuck, 2016). They extract dissolved mineral matters from water solutions applying them to form proper cellular structures.

However, the technique of water treatment with the use of hydrobionts can be applied within rather limited temperature water interval. If water cools down below a certain level, the vital activities of the hydrobionts slow down; if the temperature is negative, then their cells ruin and die. When aquatic medium temperature is higher than $27^{\circ} \mathrm{C}$, hydrobionts also terminate their development due to the lack of the dissolved oxygen. Under such conditions they are displaced by blue-green algae and other anaerobic bacteria. In the context of Donbas, a range of the listed optimum average daily air temperature determining mainly subsurface water temperature is rather limited; it takes only about six months which specifies insufficient duration of waste treatment facilities efficiency. A problem, concerning determination of biological water treatment parameters during winter season, is still topical.

Waste water is treated biologically within so-called bioplateau (Stol'berg et al., 2007). To support efficient treatment during winter season when atmospheric air is negative, it is proposed to increase sewage water level within a bioplateau system; when ice thickness is $3 \mathrm{~cm}$, it is required to develop air area between the ice layer and the sewage water level by means of the sewage disposal from the bioplateau. Heavy dependence upon the climate is the technique disadvantage. Moreover, a process of an ice layer formation needs the bioplateau operation stoppage since ice crystals cannot be formed within turbulent movable water mass where temperature is down to $-10^{\circ} \mathrm{C}$.

To prevent treatment degradation, Norwegian experts propose to use two-layer (i.e. hay + snow) isolation under the conditions of frigid climate (Wittgren \& Mæhlum, 1997). However, due to snow deficit, the technique cannot be popular in Donbas.

To overcome upper temperature threshold, when water is heated higher than $25^{\circ} \mathrm{C}$, water is treated biologically with the use of tropic heat-loving fluctuant Eichornia crassipes. The technique is as follows: at the $23-30^{\circ}$ air temperature, $25-30^{\circ}$ sewage water is supplied to a system of distributing and operating channels where water hyacinth is planted (Garsiya, Drutskaya, Drutskiy, \& Garsiya, 2009). However, the problem is that the technique is satisfactory only in summer when environment temperature is 25 to $40^{\circ} \mathrm{C}$; if water temperature drops below $20^{\circ} \mathrm{C}$, then water treatment process slows down; when water temperature is below $10^{\circ} \mathrm{C}$, the plants die. In the context of Donbas, the number of hot days is $10-25 \%$ during a warm season. Moreover, continental climatic type determines temperature jumps with significant amplitude resulting in unstable operation of a bioplateau. Autumn-spring water treatment should involve the water heating factoring into extra material and technical expenditures.

There is another biological technique of water demineralization lying in its contact with such high aquatic vegetation as common reed, common bulrush, and narrow-leaved cattail in combination with iris cultivated within special support medium; in this context, treatment process takes place under a layer of polymeric load which density is less than density of water (Zhurba \& Lyubina, 1997). However, the structure filling with polymeric layer load, being filtering element, prevents from the plant residuals bottom depositing and from the formation of a fertile layer within the industrial site to be the technique disadvantage. Furthermore, the lack of thermal protection of the biotreatment facilities will result in destruction of high aquatic vegetation during winter.

To improve the efficiency of biological treatment of waste water, bioplateau-filter system with air-lift activation of water-treatment process has been proposed (Zakharchenko et al., 2018). However, the technique of water treatment with the help of phytosystem has following disadvantage being the necessity to develop +10 to $+25^{\circ} \mathrm{C}$ temperature conditions required for its normal operation. If air temperature is below $10^{\circ} \mathrm{C}$, the bioplateau-filter system having no external thermal protective shell will not be able to perform its functions due to slowing down of vital activities of hydrobionts; if temperature is $0^{\circ} \mathrm{C}$ and below, the functions cannot be performed due to water freezing within air-lift. If water temperature is higher than $25^{\circ} \mathrm{C}$, treatment efficiency reduces significantly due to the deficiency of oxygen dissolved in the water and slowing down of activities of hydrobionts consequently.

It is proposed to apply geothermal energy for thermal sewage water stabilization over $10-25^{\circ} \mathrm{C}$ range all year round while reclamating territories disturbed by open-pit mining by means of developing a bioplateau within the worked-out area (Kostenko, Zavialova, \& Chepak, 2015). To do that, tubular geothermal heat-exchange unit is used; the device is the tubes located coaxially within a well. Inner tube is made of a material with low thermal conductivity. Water inflow into a heat exchanger, into a gap between inner tube and outer one is performed at the expense of hydrodynamic flow pressure; water, heated up to the massif temperature is supplied through the cavity of inner tube. Thus, well depth is selected in such a way to heat the water, moving within the tube space, up to $10-15^{\circ} \mathrm{C}$. While leaving a heat exchanger, it heats water in winter or cools it in summer making the development of hydrobionts comfortable.

Flows from the heat exchanger are streamed to bioplateau being a labyrinth of channels on which walls and bottom hydrobionts grow. Suspended matters, contained within the waste water, deposit at the channel bottom; however, their bulk is caught by numerous developed rootstock microvilli passing into a bound state. In this context, contents of salts and suspended matters decrease. Fertile layer, i.e. a basis for biota development, is formed from the caught particles and dying hydrobionts organs.

Depending upon structural parameters of the heat exchanger, water supplying to intertubular gap, either gets hot during cold season or gets cool during warm one; thus, the water is delivered with constant temperature.

However, the technique cannot involve obligatory water drainage from the flooded mine workings where depth is not less than $100 \mathrm{~m}$. Then, it is required to consider possible concurrent processes of soil recultivation and sewage water treatment. Unability to control temperature of water, delivered from heat exchanger, can also be considered as the technique disadvantage. 


\subsection{Purposes and objectives of the research}

Objective of the research is to mitigate the adverse environmental impact for territories and water resources in the process of liquidation of mining enterprises.

Following problems should be solved to achieve the objective:

- substantiation of efficient measures to mitigate adverse environmental impact resulting from closing down of mining enterprises;

- improvement of a biotechnology for clarification and demineralization of mine sewage water;

- experimental determination of parameters to use high water plants for sewage water treatment.

\section{METHODS}

Water content-biomass growth dynamics of common reed dependency has been studied while determining the efficiency of high water plants to treat highmineralized water.

The experimental water body is at the territory of Donetsk Region; its capacity is 50 cubic meters; it is stocked by hydrobionts, essentially by common reed representing high water plants. High-mineralized underground water, atmospheric precipitates in the form of rain, and surface flows feed the water body.

Preliminary photofixation has helped determine that growth of the reed stems within costal area of the water body is practically uniform. Thus, twelve reed tillers were selected randomly; water is the habitat for eight of the tillers, and remaining four tillers grow at the distance of up to a meter from the water level. Water temperature, air temperature, heights of the tillers, and their diameters were recorded. The samples were measured ones a week as well as sampling itself; the process lasted during 38 weeks from March 2016 to November 2017.

Water content was estimated under laboratory conditions according to the amount of the suspended matters and total salt content.

The amount of the suspended matters was determined when filtration residues of $50 \mathrm{ml}$ sample were dried out at $105^{\circ} \mathrm{C}$ to stationary mass by means of a drier with their following weighing.

Total salt content within the water under analysis was determined using a weight method when definite volume $(50 \mathrm{ml})$ of filtered water sample was evaporating into a preliminary weighted porcelain cup; at $105^{\circ} \mathrm{C}$ temperature the residues were dried out to stationary mass by means of a drier.

\section{RESULTS AND DISCUSSION}

Results of the research have helped determine that active growth phase of common reed was observed from the $2^{\text {nd }}$ of April till $25^{\text {th }}$ of June (Fig. 1). Tiller diameters were formed during the first 5 weeks of the observations. Diameter of aland tillers increased from 0.40 to $0.50-0.75 \mathrm{~cm}$. Comparable parameters of water habitating plants varied from 0.5 to $1.0 \mathrm{~cm}$. It is characteristic feature that aland plants demonstrated faster growth to compare with those, growing in water; that can be explained by more intensive soil heating. In the following, the situation changed when water heated up to $14^{\circ} \mathrm{C}$.

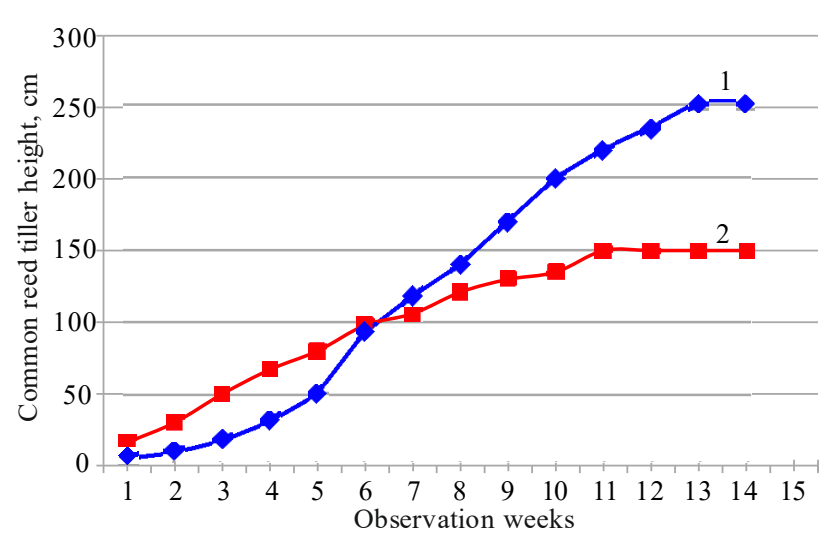

Figure 1. Dynamics of common reed tillers growth in the year of 2016: 1 -water growing plants; 2 -aland ones

During the observations, common reed tillers grew intensively almost the first 13 weeks. Maximum increment was typical for the plants, growing in water (i.e. $253 \mathrm{~cm}$ to be average index for eight tillers). In the context of aland plants, the index was almost $150 \mathrm{~cm}$. Starting from July, increment of the common reed was not more than $2-5 \mathrm{~cm}$ a week which depended upon high air temperature, and a period of the plant budding and blossoming.

Increment of a common reed, growing in water, was 1.5 times intensive to compare with the increment of aland one 2 . That can be explained by the fact that additional roots of a sample one were developed within bottom underbody of tillers. The roots absorb actively different mineral and organic matters, contained in water.

Studies, concerning the rate of a common rate tiller growth depending upon water temperature, have shown that maximum rates are observed within $12-22^{\circ} \mathrm{C}$ interval.

If we assume that common reed tissue density remains constant in the period of its growth, then it is understood that the bulk of its green material was being formed during the first 16 weeks (Fig. 2).

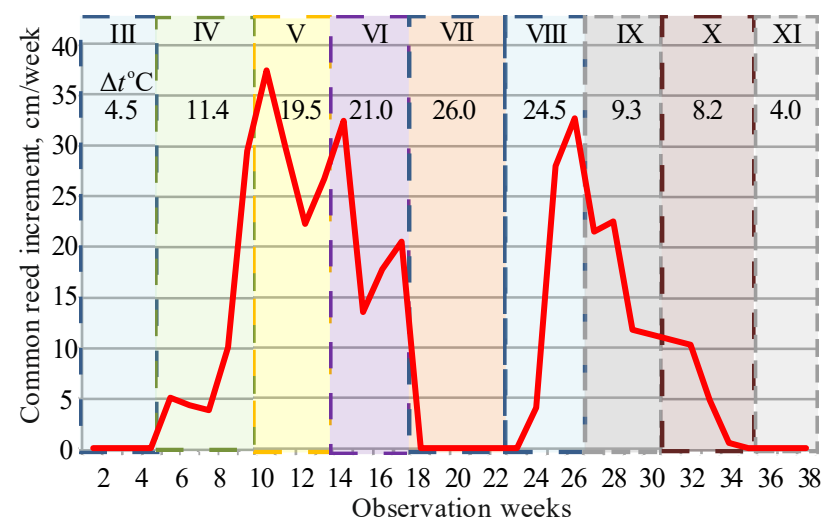

Figure 2. Dynamics of a common reed increments: III-March; IV-April; V-May; VI-June; VIIJuly; VIII - August; IX - September; X-October; $X I-$ November; $\Delta t-$ monthly mean temperature, ${ }^{\circ} \mathrm{C}$

Starting from the $17^{\text {th }}$ week, no increment of common reed was observed. That can be explained by unfavourable temperature conditions as well as the maturity of the plants. Thus, the possibility to stimulate the increased bulk of green material by means of above-water tiller portion has been considered. 
To do that, experimental samples of a common reed were cut during the $19^{\text {th }}$ week. After the process, common reed started its growth during the $24^{\text {th }}$ week only to be explained by the fact that from the $19^{\text {th }}$ till $23^{\text {rd }}$ week average day temperature was $33^{\circ} \mathrm{C}$, and water temperature was $28^{\circ} \mathrm{C}$. Starting from the $33^{\text {rd }}$ week, the common reed terminated its increment since average water temperature in the daytime was within $4^{\circ} \mathrm{C}$; at night, the water body freezed.

Laboratory analysis of water samples has helped determine that maximum salt content was observed at the end of March - early April when common reed demonstrated minimum increment (i.e. $5-10 \mathrm{~cm}$ a week). During active phase of the common reed increment (i.e. May-June) when tiller increment was $35-40 \mathrm{~cm}$ salt content in the water under analysis decreased by $17 \%$ (Fig. 3 ).

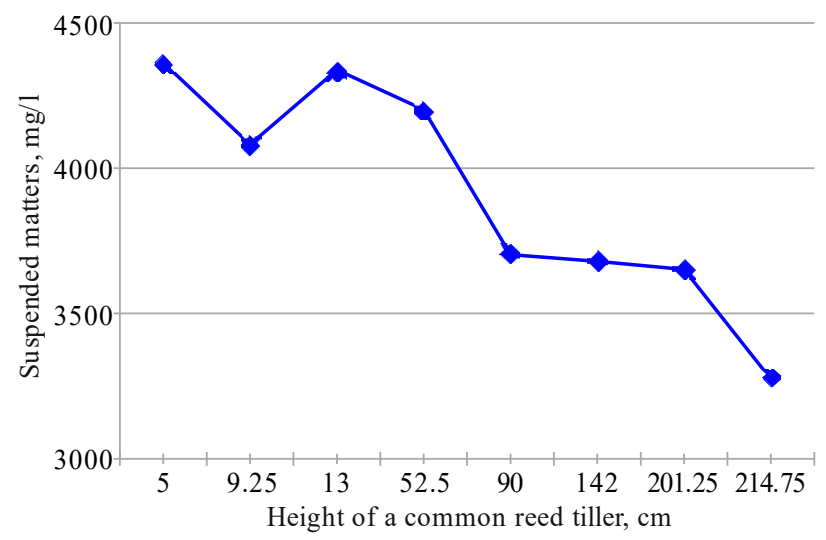

Figure 3. Dynamics of salt content variations within the water under analysis

Minimum amount of the suspended matters was observed during initial stage of the experiment when the water body contained melt water remained after winter. Starting from observation week two, abrupt jump of the index took place explained first of all by the prolonged spring rains. As a rule, if precipitation is abundant, ample quantity of suspended matters get into water from land. If there is no abundant precipitation during active phase of a common reed increment (i.e. MayJune), amount of the suspended matters decreases by $35 \%$ (Fig. 4).

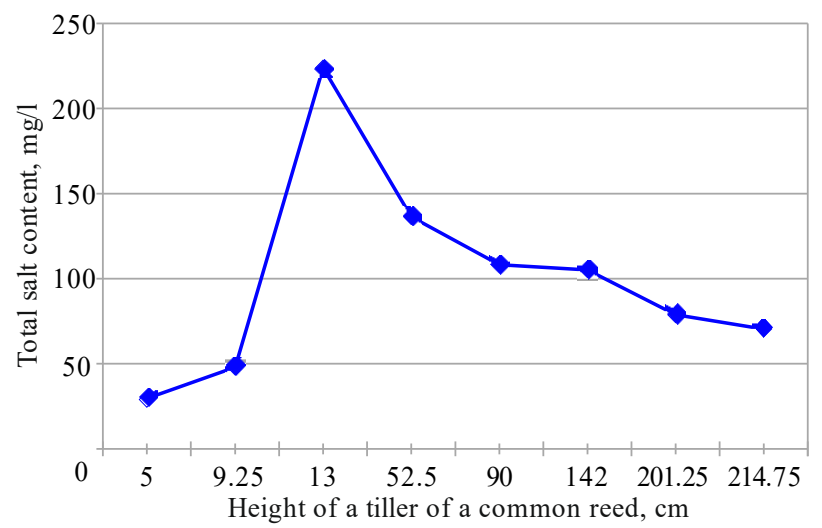

Figure 4. Dynamics of changes in the amount of the suspended matters within the water under analysis
Data of a full-scale two-year experiment have demonstrated that the development of hydrobionts within a bioplateau and its bank slopes resulted in almost 30\% decrease of total salt content during eight-month observations. Suspended matters ware caught during intensive period of a common reed growth.

To solve the specific problem of intensive restoration of disturbed land within industrial sites of the liquidated mines with synchronous treatment of sewage water, the authors propose to improve the method of their biological treatment within a bioplateau and with thermal stabilization by means of geothermal energy (Kostenko, Zavialova, \& Chepak, 2015).

In this context, flooded hoisting shaft is a heat exchanger; shift support functions as an external tube; and a pipeline of air-lift water drainage is an internal tube (Fig. 5).

(a)

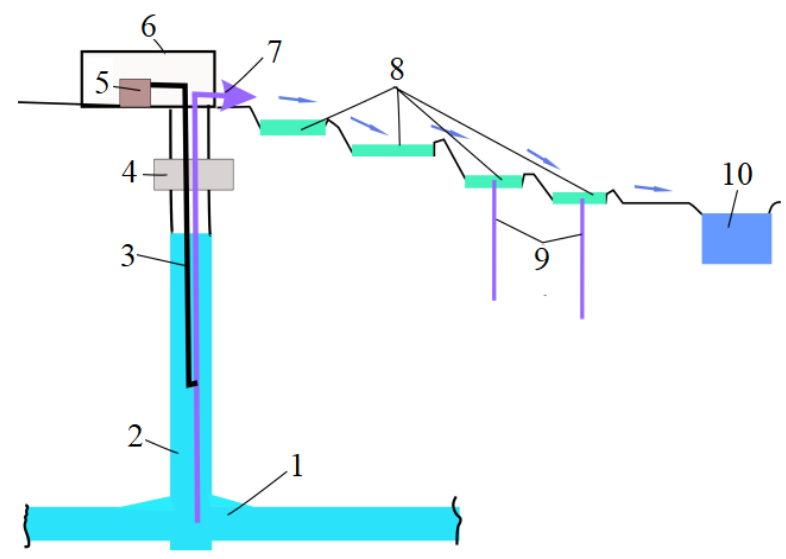

(b)

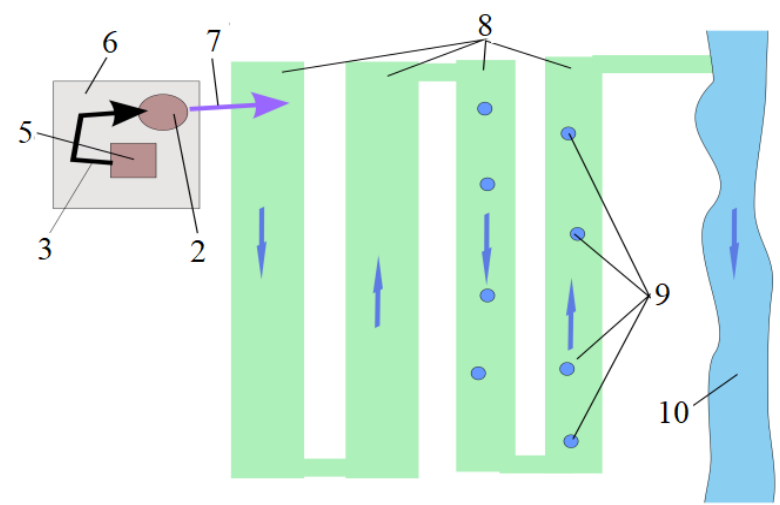

Figure 5. Procedure (a) of liquidated mines sewage water treatment and its view (b) in a scheme: 1 -flooded mine workings; 2 - hoisting shaft; 3 - a shaft for pressurized air supply; 4 - stopping; 5 - compressor; 6-pithead building; 7-flight of air lifts; 8 - bioplateau to house hydrobionts; 9 - borehole geothermal heat exchangers; 10 - water body

During cold season, warm water is pumped from the flooded level. If the weather is hot, then relatively cold water (i.e. $10-12^{\circ} \mathrm{C}$ ) is pumped from the depth of almost $100 \mathrm{~m}$ as it is prescribed by normative documents.

To control temperature conditions of sewage, certain regularity of rock mass temperature distribution while deepening has been applied. In the context of Donbas, at the depths of $5 \mathrm{~m}$ and more, soil temperature is of express- 
ly positive values within $4-12^{\circ} \mathrm{C}$. Further deepening per each $33 \mathrm{~m}$, temperature experiences one degree increase. Hence, at $100-150 \mathrm{~m}$ depths, rock mass temperature is almost $15-20^{\circ} \mathrm{C}$; at $920-950 \mathrm{~m}$ depths it is up to $45^{\circ} \mathrm{C}$.

Thus, at the expense of water, heated up certain temperature, it is possible to provide more prolonged period of activities of hydrobionts within a bioplateau; for a full year theoretically. That can guarantee more efficient treatment of sewages of mining enterprises. Moreover, formation of a fertile layer within mining allotments and industrial sites of liquidated mines takes less time owing to accumulation of plant residues within territories inha-bited by hydrobionts.

The research results may be taken as a basis to develop parameters of a technique for the disturbed territories reclamation with synchronous clarification and demineralization of sewage water to be implemented in the context of mines under liquidation as well as mines operating in water-drainage mode.

The technique of year-round mine water sewage may be used as the initial stage of water preparation for hydrolyzed treatment in the process of high grade water production.

\section{CONCLUSIONS}

1. Decreased environmental harm in the process of biological diversity restoration within industrial sites of the liquidated mines involves intensive formation of a fertile layer instead of them with synchronous treatment of mine water, pumped from the depth being no less than $100 \mathrm{~m}$. That makes it possible to reduce significantly recultivation terms of industrial sites of the liquidated mines and their return to land use.

2. Biotechnology with the use of hydrobionts, inhabiting bioplateau, is the most advantageous to treat mine sewages with synchronous formation of a fertile layer. A scheme of air-lift water drainage has been improved as for the mines which were liquidated with the use of a wet method. The scheme makes it possible to control temperature of water, being pumped out from a hoisting shaft, varying depth of its draw. Thus, a bioplateau can operate almost every day of the year.

3. The studies, concerning the efficiency of high water plants to be used for high-mineralized turbid water treatment, have confirmed the relationship between salt content and common reed biomass buildup. Prevailing increment rates are observed in the range of $12-22^{\circ} \mathrm{C}$ temperatures. Thus, that provides a basis for the following: such water temperatures will help achieve efficient biomass increment and, consequently, favour intensive formation of a fertile layer.

If temperature mode is favourable, then $32 \%$ decrease in salt content and 35\% decrease in suspended matters are guaranteed in an ordinary water body where common reed grows. The proposed method can be applied as a basic technique for mine sewage treatment as well as a preliminary one.

\section{ACKNOWLEDGEMENTS}

The findings involved neither project nor financing. Authors of the paper express thanks to the authorities of Donetsk National Technical University for the possibility to carry out the research in a chemical laboratory of the University.

\section{REFERENCES}

Chuman, T. (2015). Restoration practices used on post mining sites and industrial deposits in the Czech Republic with an example of natural restoration of granodiorite quarries and spoil heaps. Journal of Landscape Ecology, $8(2), 29-46$.

https://doi.org/10.1515/jlecol-2015-0007

Denisov, N., \& Averin, D. (2017). Otsinka ekolohichnoi shkody ta priorytety vidnovlennia dovkillia na skhodi Ukrainy. Kyiv: Vaite.

Didukh, Y., \& Aloshkina, U. (2007). Otsinka enerhetychnoho balansu ekosystem $\mathrm{m}$. Kyieva ta yoho zelenoi zony. Ukrainskyi Fitotsenolohichnyi Zbirnyk, (25), 48-56.

Dolina, L. (2000). Stochnye vody predpriyatiy gornoy promyshlennosti $i$ metody ikh ochistki. Dnepropetrovsk: Molodezhnaya ehkologicheskaya liga Pridneprov'ya.

Garsiya, A., Drutskaya, Yu., Drutskiy, A., \& Garsiya, V. (2009). Sposob ochistki stochnykh vod i ustrojstvo dlya ego osushhestvleniya. Patent No. 2356855, Rossiya.

Grebenkin, S., Kostenko, V., \& Matlak, E. (2008). Fizikokhimicheskie osnovy tekhnologii demineralizatsii shakhtnykh vod. Donetsk: Vik.

Gusev, N., Kaplunov, Y., \& Podsevalov, A. (2010). Ochistka shakhtnykh vod do pit'evogo kachestva na likvidirovannykh shakhtakh. Gornyy Informatsionno-Analiticheskiy Byulleten'. Nauchno-Tekhnicheskiy Zhurnal, (2), 308-313.

Ivakina, E., \& Osipov, S. (2016). Natural and artificial reforestation in the mining landscapes of the Russian Far. East Sibirskij Lesnoj Žurnal, 3(2), 6-21. https://doi.org/10.15372/sjfs20160201

Kaplan, D. (2012). Instability in newly-established wetlands? Trajectories of floristic change in the re-flooded Hula peatland, northern Israel. Mires and Peat, 9(05), 1-10.

Kostenko, V., Mnukhin, A., \& Omelchenko, M. (2013). Povodzhennia z shakhtnymy vodamy. Donetsk: DonNTU.

Kostenko, V., Zavialova, E., \& Chepak, O. (2015). Vidnovlennia biolohichnoho riznomanittia $\mathrm{v}$ vyroblenykh karieriv. In XII Mizhnarodna Naukovo-Praktychna Konferentsiia "Problemy Ekolohichnoi Bezpeky" (pp. 85-86). Kremenchuk: KrNU.

Reznikov, Y., L'vov, V., \& Kul'chenko, V. (2003). Shahtnye $i$ kar'ernye vody. Konditsionirovanie, ispol'zovanie, obessolivanie i kompleksnaya pererabotka. Donetsk: Kashtan.

Romanchuck, L.D. (2016). Hydrophyte water purification under conditions of "Zhitomyrvodokanal" communal enterprise. Biotechnologia Acta, 9(6), 58-71. https://doi.org/10.15407/biotech9.06.058

Stol'berg, F., Ladyzhenskiy, V., Kislitsa, A., Ishhenko, A., Vergeles, Y., \& Lobov, A. (2007). Sposob biologicheskoy ochistki tochnykh vod. Patent No. 24676, Rossiya.

Tropek, R., \& Konvicka, M. (2008). Can quarries supplement rare xeric habitats in a piedmont region? Spiders of the Blansky les Mts, Czech Republic. Land Degradation \& Development, 19(1), 104-114. https://doi.org/10.1002/ldr.817

Wittgren, H., \& Mæhlum, T. (1997). Wastewater treatment wetlands in cold climates. Water Science and Technology, 35(5), 45-53. https://doi.org/10.1016/s0273-1223(97)00051-6

Zakharchenko, M.A., Moshynskyi, V.S., Kuryliuk, A.M., Zlakoman, S.L., $\quad$ Kucheruk, M.H., $\quad$ Direnko, H.O., Kuryliuk, O.M., Bondar, O.I., Kryvoshei, P.P., Podzerei, S.O., Broshuk, I.S., Aiaia, A., Kuryliuk, M.S., Filipchuk, V.L., \& Pochtar, O.V. (2018). Uzv-kompleks bioplato-filtr iz erliftnoiu aktyvatsiieiu laguna-gryn.154. Patent No. 122917, Ukraina.

Zhurba, M., \& Lyubina, T. (1997). Sposob biologicheskoy ochistki vody ot soley. Patent No. 2094392, Rossiya. 


\title{
ЗНИЖЕННЯ НЕСПРИЯТЛИВИХ ЕКОЛОГІЧНИХ НАСЛІДКІВ ЛІКВІДАЦІЇ ГІРНИЧОДОБУВНИХ ПІДПРИЕМСТВ
}

\section{В. Костенко, О. Зав’ялова, О. Чепак, В. Покалюк}

Мета. Зниження несприятливих екологічних наслідків для території та гідроресурсів при ліквідації гірничодобувних підприємств.

Методика. Експериментальні та лабораторні дослідження взаємозв'язку між солевмістом і кількістю приросту біомаси очерету звичайного. Для досліджень обрано 12 відростків очерету зі ставка у Донецькій області об'ємом 50 м³, 3 яких 8 - ростуть у воді, а 4 - на відстані до 1 метра від урізу води. Реєструвалася температура води і повітря, довжина стебел очерету, а також їх діаметр протягом 38 тижнів (березень - листопад). Кількість зважених речовин визначалася висушуванням в сушильній шафі залишку на фільтрі після фільтрування проби 50 мл і наступним зважуванням, а загальний солевміст у досліджуваній воді визначався ваговим методом - шляхом випарювання 50 мл об'єму профільтрованої проби води з попередньо зваженої ємності та висушування залишку.

Результати. Підтверджено взаємозв'язок між солевмістом і кількістю приросту біомаси очерету звичайного, а також встановлено температурний діапазон, при якому спостерігався найбільший приріст біомаси на підставі дослідження ефективності застосування вищих водних рослин для очищення високомінералізованих мутних вод. Удосконалено, стосовно до дренажного водовідведення ліквідованих “мокрим" способом шахт, схема ерліфтного водовідливу, що дозволяє регулювати температуру вод, що відкачуються, змінюючи глибину їх відбору з шахтного стовбура, що дозволяє забезпечити практично цілорічну роботу біоплато.

Наукова новизна. Вперше теоретично встановлено та експериментально підтверджено оптимальний температурний режим води в біоочисному спорудженні $12-22^{\circ} \mathrm{C}$, при якому забезпечується цілорічне зниження загального солевмісту води на $32 \%$, а кількість завислих речовин - на $35 \%$.

Практична значимість. Отримані результати можуть застосовуватися для відновлення родючого шару грунту на порушених територіях промислових майданчиків ліквідованих гірничодобувних підприємств, з одночасним очищенням стоків від солей і завислих речовин.

Ключові слова: рекультивачія, біологічне різноманіття, біоплато, родючий шар, вищі водні рослини, ліквідована шахта

\section{СНИЖЕНИЕ НЕБЛАГОПРИЯТНЫХ ЭКОЛОГИЧЕСКИХ ПОСЛЕДСТВИЙ ЛИКВИДАЦИИ ГОРНОДОБЫВАЮЩИХ ПРЕДПРИЯТИЙ}

\author{
В. Костенко, Е. Завьялова, О. Чепак, В. Покалюк
}

Цель. Снижение неблагоприятных экологических последствий для территории и гидроресурсов при ликвидации горнодобывающих предприятий.

Методика. Проведены экспериментальные и лабораторные исследования взаимосвязи между солесодержанием и количеством прироста биомассы тростника обыкновенного. Для исследований выбраны 12 отростков тростника из пруда в Донецкой области объемом $50 \mathrm{~m}^{3}$, из которых 8 - растут в воде, а 4 - на расстоянии до 1 метра от уреза воды. Регистрировалась температура воды и воздуха, длина стеблей камыша, а также их диаметр на протяжении 38 недель (март - ноябрь). Количество взвешенных веществ определялось высушиванием в сушильном шкафу остатка на фильтре после фильтрования пробы 50 мл и последующим взвешиванием, а общее солесодержание в исследуемой воде определялось весовым методом - путем выпаривания 50 мл объема профильтрованной пробы воды и высушивания остатка.

Результаты. Подтверждена взаимосвязь между солесодержанием и количеством прироста биомассы тростника обыкновенного, а также установлен температурный диапазон, при котором наблюдался наибольший прирост биомассы на основании исследования эффективности применения высших водных растений для очистки высокоминерализованных мутных вод. Усовершенствована, применительно к дренажному водоотведению ликвидированных “мокрым" способом шахт, схема эрлифтного водоотлива, позволяющая регулировать температуру откачиваемой воды изменяя глубину ее отбора из шахтного ствола, что позволяет обеспечить практически круглогодичную работу биоплато.

Научная новизна. Впервые теоретически установлен и экспериментально подтвержден оптимальный температурный режим воды $12-22^{\circ} \mathrm{C}$ в биоочистній споруді на территории ликвидированной шахты, при котором обеспечивается круглогодичное снижение общего солесодержания воды на $32 \%$, а количество взвешенных веществ - на $35 \%$.

Практическая значимость. Полученные результаты могут применяться для восстановления плодородного слоя почвы на нарушенных территориях промышленных площадок ликвидированных горнодобывающих предприятий, с одновременной очисткой стоков от солей и взвешенных веществ.

Ключевые слова: рекультивачия, биологическое разнообразие, биоплато, плодородный слой, высиие водные растения, ликвидированная шахта 


\section{ARTICLE INFO}

Received: 13 March 2018

Accepted: 10 September 2018

Available online: 26 September 2018

\section{ABOUT AUTHORS}

Viktor Kostenko, Doctor of Technical Sciences, Head of the Department of Environmental Activities, Donetsk National Technical University, 2 Shybankova Ave., 85300, Pokrovsk, Ukraine. E-mail: vk.kostenko@gmail.com

Olena Zavialova, Candidate of Technical Scienceis, Associate Professor of the Department of Environmental Activities, Donetsk National Technical University, 2 Shybankova Ave., 85300, Pokrovsk, Ukraine. E-mail: elenazavialova@,rambler.ru

Olha Chepak, PhD Student of the Department of Environmental Activities, Donetsk National Technical University, 2 Shybankova Ave., 85300, Pokrovsk, Ukraine. E-mail: olha.chepak@donntu.edu.ua

Victor Pokalyuk, Candidate of Pedagogical Sciences, Head of the Department of Fire Tactics and Rescue Operations, National University of Civil Defence of Ukraine, 94 Chernyshevska St, 61023, Kharkiv, Ukraine. E-mail: vpokaluk@ukr.net 